\title{
Com-educational Platforms: Creativity and Community for Learning
}

\author{
Iván Sánchez-López ${ }^{1} \odot$, Amor Pérez-Rodríguez $^{2} \odot$ and Manuel Fandos-lgado ${ }^{3} \odot$
}

\author{
${ }^{1}$ Doctorando en Doctorado Interuniversitario en Comunicación, Universidad de Huelva, España \\ ${ }^{2}$ Department of Philology, University of Huelva, Spain \\ ${ }^{3}$ Faculty of Education, University of La Rioja, Spain
}

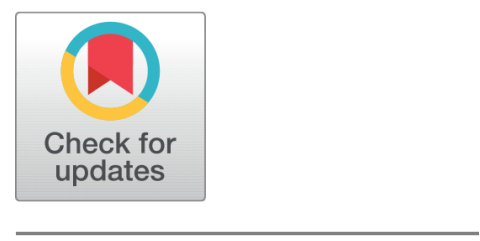

Received 14-05-2019

Revised 16-05-2019

Accepted 23-05-2019

Published 15-07-2019

\section{Corresponding Author}

Iván Sánchez-López,

isanchez@oij.org

Universidad de Huelva, Facultad de Humanidades, Campus del Carmen, s/n, Huelva 21007, Spain

DOI https://doi.org/10.7821/ naer.2019.7.437

Pages: 214-226

Funding: Ministerio de Ciencia, Innovación y Universidades de España \& Fondo Europeo de Desarrollo Regional (FEDER) (RTI2018-093303-B-I00)

Distributed under

Creative Commons CC BY 4.0

Copyright: (C) NAER Journal of New Approaches in Educational Research 2019

\section{OPEN ACCESS}

\section{ABSTRACT}

Education is at a time of redefinition and transformation, in line with an era characterized by considerable technological development and profound social changes. One would expect it to be accompanied by a media context in which narrative models are transformed by the impact of digitalization, affecting student-teacher interactions. However, it has been observed that the media usage of an entire generation emphasizes the gap between formal education and young people's everyday digital life. Within this framework, and at the international level, a series of innovative pedagogical proposals have emerged, which approach education from the field of communication: Minecraft Education, NFB Education, Educ'Arte, Scratch and 7 de Cinema. We have called them com-educational platforms, because of their investment in the education-communication vector, based on an educommunicative idea. The proposed study implements a multimodal discourse analysis (MDA) to gain an in-depth knowledge of its characteristics. Beyond their individual idiosyncrasies, our analysis reveals a common central feature: the placement of community-creativity combination as the core phenomenon for learning.

\section{Keywords COMMUNICATION, EDUCATION, DIGITAL, CREATIVITY,} COMMUNITY

\section{INTRODUCTION}

After the universalization of education as a system in the Nation-States of the so-called developed world, we still find ourselves far from the goal of universal education set by the UN in the year 2000. Education, as an institution, faces what could be catalogued as its greatest challenge in the $21^{\text {st }}$ century: the re-definition of its role and the complete re-conversion of its fundamentally transmissive and uni-directional processes, linked to behaviorism, to teach how to learn or guide learning in a liquid world (Area \& Ribeiro, 2012; Bauman, 1999), with the macro-influences of capitalism, consumerism and globalization (Bazzul, 2012), the digital revolution (Jenkins, 2008; Manovich, 2005), media convergence and the need for 
literacy (Buckingham, 2007; Pérez-Rodríguez, Contreras-Pulido, \& Delgado-Ponce, 2018; Pérez-Tornero \& Martínez-Cerdá, 2011), and participative culture (Jenkins, Purushotma, Weigel, Clinton, \& Robison, 2009; Scolari, 2018).

In this context, didactics, which one would assume should be ahead or at least in tune with technological development, has been clearly exceeded (Gutiérrez \& Tyner, 2012; PérezRodríguez, Delgado-Ponce, García-Ruiz, \& Caldeiro, 2015). Digital media, for their part, complicate the idea of a singular text, with environments that are more complex in the number of participants, density of interaction and rhythm of change (Considine, Horton, \& Morrman, 2009; Naughton, 2010), while literacy, from formal education, seems to be relegated to the traditional principles of reading and writing (voice, book, paper, pencil). The new ways of thinking "in another, more kaleidoscopic and more fragmented manner, more visual, faster, more interactive" (Pérez-Rodríguez \& Delgado-Ponce, 2012, p. 26) question and collide with the current pedagogic school planning.

With the removal of the monopolistic veil of old media (Jenkins, 2008), and once the technical opening to media broadcasting has been globalized (in spite of its divides), the gaps and misgivings of the traditional educational systems have become more explicit when addressing the new media scenario. Narrative usage of an entire generation of neophyte storytellers only serves to highlight the existing distance between the lived reality of youth, and the educational proposal that shapes them (Pérez-Rodríguez, Pérez-Escoda, \& SánchezLópez, 2019). For the contemporary emirec (Cloutier, 1973) schools still offer, in the best of cases, a teaching solution, as opposed to the reception or consumption, relegating and denying the transformative power of creation and diffusion (connected communication). Paradoxically, according to Bruns and Schmidt (2011), young people, in this digital media system, simultaneously produce and use, as active users of content and information, coining the term producers.

In the last few years, a great effort has been made in the educommunication and media literacy fields to question and revert this situation (Aguaded, 2012; Aparici \& Silva, 2012; Ferrés, Aguaded, \& García-Matilla, 2012; Ferrés \& Piscitelli, 2012; Gutiérrez \& Tyner, 2012; Livingstone, 2012; Pérez-Tornero, 2013).

Alongside academic research, a series of innovative methodologies have recently been incorporated, especially at the international level, which place the learner's creative process at (García, Rigo, \& Jiménez, 2017). Thus, PLE, PBL, Design Thinking, the DIY, the maker movement... show Piaget (2007) and Vygotsky (2004) legacy in the digital context.

Similarly, a series of experiences merged with media environments that are as diverse as the videogame, the documentary, or film, have began to approach education, in a line which we have named com-education. These are projects such as Minecraft Education, NFB education, Educ'Arte, Scratch or the 7 de Cinema suitcase, which recover logics from their fields to apply them to formal and non-formal learning environments.

Minecraft Education is the educational version of the famous Minecraft videogame, developed by Mojang and acquired by Microsoft in 2014. NFB education belongs to the National Film Board, the public agency from the Canadian Government for the production and distribution of films and digital media. Educ'Arte is the digital platform created 
by the French-German channel Arte, which is a pedagogic proposal constructed from the audiovisual archive of the corporation. Scratch is a programming language and a community model developed by the Lifelong Kindergarten of the MIT MediaLab. The 7 de Cinema suitcase, for its part, is a didactic proposal created by the Catalonian Film Library, Eduxarxa and the Cinema Museum - Tomàs Mallol Collection.

The scientific literature recognizes significant contributions from these platforms. Thus, in the case of Scratch, the programming and the development of knowledge is recognized (Franklin et al., 2013; Tondeur et al., 2012), and in Minecraft Education's proposal, Cipollone, Schifter, and Moffat (2014) argue that it offers a unique opportunity for students to show their creativity and their comprehension in ways that are more tangible than if they were conducted in the "real world".

\section{METHOD}

The objective of the present research study is to analyze the educommunicative characteristics of the platforms, which, from mediated communication, are being linked with learning. For this, a DA (discourse analysis), a clear trend in Human and Social Sciences (Santander, 2011), was performed, as a tool that will allow us to unravel the characteristics of discourse, content and shape or form, as related to a topic. In this sense, the MDA (multimodal discourse analysis) was utilized to reveal the formulas used by the professional communication field for the teaching-learning, leaning towards issues of form, content and context (textual and contextual analysis). Within the framework that forms part of multimodal analysis, and leaning towards the specifics of the research, the proposal by Pauwels (2012) was utilized as the starting point, as it places values on semiotic elements as well as their contextual/cultural links in a holistic manner. Nevertheless, an adaptation was made (added in italics) of the categories considered by Pauwels (2012), which can be observed in Table 1, to address the com-educational components of the corpus more specifically, from both digital and analog platforms. The adaptation is made over the consideration of the theoretical framework of our work and our object of analysis, from a perspective that emerges from mediated communication and an orientation towards creation.

Non-probabilistic sampling was conducted, framed within the denominated subjective sampling by reasoned decision (purposive sampling), in which the sample units are not chosen through probabilistic methods, but according to some of their characteristics (Corbetta, 2007). Thus, our discursive sample includes the following web platforms that implement mediated communication for learning: Minecraft Education (Sweden - United States), National Film Board Education (Canada), Educ'Arte (France), Scratch (United States) 7 de Cinema (Spain).

\section{RESULTS}

The analysis conducted, following the proposal by Pauwels (2012), has allowed us to decipher the main characteristics and the functionalities of the platforms around 4 aspects: Self- 
Table 1 Codebook

\section{Project name:}

Year of creation:

Project Manager:

Main slogans:

Target audience:

\section{FIRST IMPRESSIONS AND REACTIONS}

a) Categorize impressions at first sight

b) Record affective reactions

\section{VISUAL INVENTORY OF HIGHLIGHTS AND THEMES}

2.1. Inventory of main characteristics and attributes

2.2. Inventory of com-educational praxis

2.3. Inventory of main content, categories and themes

\section{CONTENT ANALYSIS AND FORMAL ASPECTS}

3.1. Intermodal analysis (fixed/static and moving/dynamic elements)• Verbal/written signifiers

- Typographical signifiers

- Visual representation signifiers

- Audio signifiers

- Design signifiers

- Metaphors

- Symbols

3.2. Crossmedia analysis of the interface $\bullet$ Relations between images/text and typography

- Relations between sound/image

- General design/interactions between image, audio and text

3.3. Use of the 5 key digital network strategies $\bullet$ HYPERMEDIA

- INTERACTIVITY

- VIRTUALITY

- TRANSMEDIA

- CONECTIVITY / PARTICIPATION

4. INTEGRATED VIEWPOINTS (VOICE), AUDIENCE INVOLVED AND PURPOSES

- Analysis of viewpoints and personification

- Analysis of primary and secondary audiences

- Analysis of integrated objectives and purposes

\section{ANALYSIS OF CONTEXT, PROVENANCE AND INFERENCES}

Identification of the emitters and their sources

Technological platforms and their implications and constraints

\section{ANALYSIS OF THE ORGANIZATION OF INFORMATION AND STRATEGIES OF MOTIVATION / COMMITMENT AND CREATIVE EMPOWERMENT}

- Structure and navigation options and restrictions (dynamic organization)

- Analysis of strategies for motivation/commitment

- Specific analysis of the 5 key digital network strategies for motivation/commitment

- Analysis of strategies to generate a community around the proposal

- Analysis of strategies for narrative empowerment of users

Source: Ataptation of Pauwels (2012) 
Table 2 Presentation of Plataforms

\begin{tabular}{|c|c|c|c|}
\hline & Emitter & Target & Claim \\
\hline $\begin{array}{l}\text { Minecraft } \\
\text { EducMCE }\end{array}$ & $\begin{array}{l}\text { Mojang AB, 4J Studios, Microsoft } \\
\text { Studios }\end{array}$ & $\begin{array}{l}3-18+\text { year-olds } \\
\cdot \text { Open (paid) } \\
\cdot \text { Educational community } \\
\cdot \text { Focus on education }\end{array}$ & $\begin{array}{l}\text { Engage Students in fun new ways } \\
\cdot \text { Explore a world of learning. } \\
\text { - Asses and Reflect / Inmersive learning / Classroom } \\
\text { Collaboration } \\
\cdot \text { 22nd Century skills! }\end{array}$ \\
\hline $\begin{array}{l}\text { NFB Educ } \\
\text { NFBE }\end{array}$ & National Film Board Canada & $\begin{array}{l}\text { - Educational community (open } \\
\text { to new learning spaces) } \\
\text { - Variable - by project } \\
\text {. School and high-school }\end{array}$ & $\begin{array}{l}\text { The new online media solution for today's class- } \\
\text { room. } \\
\text { - Turn your classroom or your library into a film stu- } \\
\text { dio! } \\
\text { - Foster deep learning and creativity, sharpen criti- } \\
\text { cal thinking, promote digital literacy. }\end{array}$ \\
\hline $\begin{array}{l}\text { Educ'Arte } \\
\text { EAR }\end{array}$ & ARTE France Développement. & $\begin{array}{l}\text { Comunidad educativa } \\
\text { École, collège, Lycée }+ \text { non- } \\
\text { formal spaces } \\
\text { - Separation faculty/students }\end{array}$ & $\begin{array}{l}\text { 500+ vidéos. } \\
\text { Créez, Partagez. } \\
\text { Simple, social. }\end{array}$ \\
\hline $\begin{array}{l}\text { Scratch } \\
\text { SCR }\end{array}$ & $\begin{array}{l}\text { Lifelong Kindergarten en el MIT } \\
\text { Media Lab. }\end{array}$ & $\begin{array}{l}8-16 \text { year-olds } \\
\text { Open }\end{array}$ & $\begin{array}{l}\text { Imagine, Program, share. } \\
\text { - Create stories, games and animations. Share with } \\
\text { people from around the world. } \\
\text {. Scratch: Programming for all. }\end{array}$ \\
\hline $\begin{array}{l}7 \text { de Cinema } \\
\text { 7DC }\end{array}$ & $\begin{array}{l}\text { Eduxarxa, Filmoteca de Catalunya, } \\
\text { Museu del cinema Col·lecció Tomàs } \\
\text { Mallol. }\end{array}$ & $\begin{array}{l}\text { Baccalaureate and Mandatory } \\
\text { Secondary Education. Separa- } \\
\text { tion faculty/students }\end{array}$ & $\begin{array}{l}\text { - Sala 1: Tècnica: de què està fet el setè art? } \\
\text { - Sala 2: Creativitat: com es narren les històries? } \\
\text { - Sala 3: Acció. Qui fa les pellícules? }\end{array}$ \\
\hline
\end{tabular}

representation, signifiers, digital drivers and media-related creative praxis. Table 2 shows how each platform is self-represented as per the emitter, the target and the claim.

The MDA reveals, as shown on Table 2, an emphasis on creativity when the platforms are self-represented, and in the repeating concept of sharing and collaborating.

These two notions mark a differential focus connected with constructivism, cognitivism and connectivism while abandoning principles of behaviorism. These are also related to proposals such as PBL (Project Based Learning) and the maker movement. Each of these highlights their media potential, integrating a notion of contemporaneity and new skills, beyond reading-writing. The integration of other media forms is associated here with the idea of validity and the current nature of educational processes.

Their target audience is similar (school and high school in the different countries), although the level of openness is variable - in NFB, community centers are explicitly cited, for example - moving closer to non-formal education. Minecraft and Scratch, are oriented towards younger audiences.

With respect to the signifiers found on Table 3, the analysis shows an increase in importance of the visual elements in the proposals to the detriment of writing, with the reference image being the most commonly utilized. In the didactic guides or downloadable documents, however, the text still takes up most of the space. The elements of design (graphics, icons, etc.), also gain importance, and tend to re-enforce the corporate identity of the platform itself. The music and auditory elements, for their part, are not usually utilized on the basis of the platforms, being confined to the diegesis of the hyper-mediated projects they 
Table 3 Use of verbal/written signifiers, visual, auditory and design-based by platform.

\begin{tabular}{|c|c|c|c|c|}
\hline & Verbal/written signifiers & Visual representation & Audio & Design \\
\hline MCE & $\begin{array}{l}\text { Three functions: } \\
\text {-Comunication - Chat. } \\
\text {-Instructional: Panels. } \\
\text {-Informational/Drama: NpC's. }\end{array}$ & $\begin{array}{l}\text { It is derived from the mimesis } \\
\text { of the real referential world, } \\
\text { mutated into pixels/blocks } \\
\text { and introducing elements of } \\
\text { its own imaginary. }\end{array}$ & $\begin{array}{l}\text { Minimalist music. } \\
\text { Autonomously, the world } \\
\text { and its inhabitants generate } \\
\text { their own sounds. }\end{array}$ & $\begin{array}{l}\text { Blocks/pixels as a distinctive ele- } \\
\text { ment. } \\
\text { Extensive color palette. Editable. }\end{array}$ \\
\hline NFBE & $\begin{array}{l}\text { Referential-informative } \\
\text { explanatory value. }\end{array}$ & $\begin{array}{l}\text { Diegetic still images are used } \\
\text { to articulate projects and } \\
\text { their content. }\end{array}$ & $\begin{array}{l}\text { Music and diegetic voices in } \\
\text { audiovisual and interactive } \\
\text { projects. }\end{array}$ & $\begin{array}{l}\text { Great emphasis on image. Min- } \\
\text { imalist, considering accessibility } \\
\text { and functionality. Color sepa- } \\
\text { rates sections. }\end{array}$ \\
\hline EAR & $\begin{array}{l}\text { Referential-informative } \\
\text { explanatory value. }\end{array}$ & $\begin{array}{l}\text { Diegetic still images are used } \\
\text { to articulate projects and } \\
\text { their content. }\end{array}$ & $\begin{array}{l}\text { Music and diegetic voices in } \\
\text { audiovisual and interactive } \\
\text { projects. }\end{array}$ & $\begin{array}{l}\text { Blog-based design, without } \\
\text { major fanfare. Preponderance } \\
\text { of corporate color. Emphasis of } \\
\text { image. }\end{array}$ \\
\hline SCR & $\begin{array}{l}\text { Referential-informative and } \\
\text { explanatory value with nods at the } \\
\text { target audience. }\end{array}$ & $\begin{array}{l}\text { Diegetic still images are } \\
\text { used to articulate projects } \\
\text { and their content. Constant } \\
\text { appeal to the visual universe } \\
\text { of Scratch. }\end{array}$ & $\begin{array}{l}\text { Audio in projects. Sound ele- } \\
\text { ments are part of the editor } \\
\text { scripts. }\end{array}$ & $\begin{array}{l}\text { Minimalist, considering accessi- } \\
\text { bility and functionality. Infantile } \\
\text { general tone. Emphasis on the } \\
\text { image. }\end{array}$ \\
\hline 7DC & $\begin{array}{l}\text { Referential-informative and } \\
\text { explanatory value with central } \\
\text { emphasis. }\end{array}$ & $\begin{array}{l}\text { Iconography is used to cate- } \\
\text { gorize (nod to film). } \\
\text { There are film excerpts. }\end{array}$ & $\begin{array}{l}\text { No inclusion of audio ele- } \\
\text { ments (only in film extracts) }\end{array}$ & $\begin{array}{l}\text { Physical objects represent iconic } \\
\text { elements from film. Colors serve } \\
\text { to categorize. }\end{array}$ \\
\hline
\end{tabular}

collect.

In the case of the Minecraft Education Universes, there is an exception to these general observations. The virtual space where the lessons are given is a visual representation of a whole in the form of immersive digital environments in three dimensions that imitate reality and expand them through its own imaginary. The logic of the desktop interface is substituted by a simulated space-time that also incorporates a dramatic sensibility.

As for the technological potential, an application that follows the traditional platforms is observed, with a few innovative proposals that are precisely oriented towards creation and collaboration, as shown on Table 4.

The hypermediated construct, in most of the cases, follows the logic of a repository, where the use of metadata and the categorization of the information are clearly oriented towards the accessibility and usability of the projects. Interactivity, in the first layer of depth, tends to be employed for traditional click and go usage. However, and this is where one of the novelties of the platform is rooted, elements are added to be able to create starting with the materials that are offered. In the case of Educ'Arte and the NFB Education, the selection of materials and the creation of playlists or hypermediated mental maps is facilitated. Scratch has its own editor, with the function to re-invent previous projects (taking the basis of a project and re-shaping it, in a dynamic that is commonly found in the programming community). Minecraft Education introduces this creative logic, inherited from the videogame itself and its options of construction/destruction of the environment and the crafting (making of elements). 
Table 4 Analysis of the 5 key digital network strategiesand their implementation in the platforms

\section{MCE}

Interactivity

Hypermedia

Transmedia

Logic

Virtuality

Conectivity/participation

\section{NFBE}

Interactivity

Hypermedia

Transmedia

Logic

Virtuality

Conectivity/participation

\section{EAR}

Interactivity

Hypermedia

Transmedia

Logic

Virtuality

Conectivity/participation

\section{SCR}

Interactivity

Hypermedia

Transmedia

Logic

Virtuality

Conectivity/participation

\section{DC}

Interactivity

Hypermedia

Transmedia

Logic

Virtuality

Conectivity/participation
In their worlds, users can interact with other users, with the world itself and with NPCs.

The hypermedia structure generates pop ups of contextual elements that highlight the text. Also hyperlinks to external websites. Clear link between web and diegetic game space. Core in game, educational approach from web to game.

The virtual environment is immersive, with a first-person avatar vantage point in an infinite procedural world.

Multi-user in a shared virtual world: teacher-mediated participation. From the web, connectivity between teachers is encouraged.

"Click and go" interactivity. In projects, there are multiform proposals for interactivity. It offers a materials editor and the option to create playlists.

The hypermedia structure is generated as a categorized showcase of multimedia materials, a large thematic repository with training purposes.

Core in NFB projects on which educational proposals are created (bundle, guides, live webinars, workshops...). Vectors towards blogs, RRSS, face-to-face workshops.

Interface-like environment (desktop mode) accessible and usable. Generates the feeling of one's own universe.

Categorized and orderly access to NFB materials. Connection through external links. Teacher-mediated participation. Link to RRSS.

"Click and go" interactivity. Recommendations are generated according to records. Enables the creation of mind maps, pedagogical sequences and video editing.

File logic architecture. Hyperlinks text, symbols and audiovisuals without dramatic purposes.

Core in ART projects and adaptation to the training environment.

Interface-like environment (desktop mode) accessible and usable. Generates a sense of one's own universe

Promotes participatory use (creation), community generation (sharing) with an internal network (under registry). Link to RRSS.

It goes beyond reproduction, generating a dynamic system in the combination of creation, exploration and contribution in an active community ecosystem. Reinvention application.

Virtually all content is hypermediated. The architecture pursues accessibility and usability without dramatic aspirations (only character recognition).

Multiple satellites around the editor and the community. Articles, books, videos in Youtube... No apparent pre-designed strategy.

Interface-like environment (desktop mode) accessible and usable. It uses characters that are incorporated into the editor to create their own Universe. The community contributes to the creation of the Digital Universe.

Participation is its backbone. The platform, as well as the search for community dynamization, generates an environment that promotes creation, collaboration and participation. It is a holistic environment.

Real interaction with objects promoted from Activities. Encourages exchange between team members.

Text linked to objects through activities in analogical hyperlinks. With videos, classic playback function.

Connection narrative between film and the classroom. No feedback strategy.

Analog environment, except for the DRIVE repository in the cinema library in the form of videos distributed in folders.

Beyond the people who are part of the classroom community (teacher-student), there is no orientation towards the participation of personalities outside the education system, or the connection with other classrooms or learning centers. 
The design of the platforms is clearly oriented towards the creation of a community, and practically all of them offer tools for the exchange and socialization of the content. Thus, 7 de Cinema would be the most limited, as it focuses on processes in the classroom starting with the suggestions of activities. Scratch, on its part, would be a clear example of the model functioning of a community that is strategically thought about and operational, facilitating the interaction between people and groups starting with individual profiles, the projects and functions such as the forum, wiki, "like" and "comments".

Connectivity and participation tend to be integrated in the platform itself, placing the personal identity, through the registration, as one of its keys, leaving in the background the links to social networks or links to other spaces in the network. The strategy of creating a logic of transmedia implementation is limited, given the sensation that the ramifications of the platforms provide along the way, without a pre-determined plan. On many occasions, the transmedia satellite on the pre-existing nucleus (non-narrative) is the platforms themselves. The NFB Education, with its extensive and expansive work on the materials (with the bundle and didactic guides), expands to in-person workshops and live webinars with experts on subjects addressed in the audiovisual projects.

The virtual models answer the interface-desk, with small exceptions in the diegesis of materials created by Arte, NFB or the Scratch users. Once again the difference is provided by Minecraft Education, with its immersive environment and the first-person perspective. This implies an alteration of the rest of the keys, which work here according to the laws of the game itself [interaction with the rest of the users in real time, with the NPCs (non-player characters) and with the environment, capacities in the diegesis that are impossible in the referential world, external links...] along with the webpage's approach, which it is now in agreement with the rest of the proposals (model of community, click and go, etc.).

The different platforms include explicit technological and methodological approaches for media creation, as shown on Table 5.

The approach, although limited, attempts to offer a differential perspective, in which media competence is not only assessed from a theoretical viewpoint, but makes sense in practice. This practice is driven by the technological tools developed specifically for the platforms. Each one presents its own proposal as a function of its idiosyncracy, but all have an element in common: they all seek the socialization of creation in an environment of community, pursuing the motivation and commitment of their users.

\section{DISCUSSION}

The analysis of com-educational platforms, Minecraft Education, NFB Education, EducArte, Scratch and 7 de Cinema reveal a focus change in the approach to learning, with creativity and community emerging as the main elements of their proposals.

The transformations of language (Martín, 2008) and learning (Pereira, Fillol, \& Moura, 2019) synthesized by Gee and Hayes (2011) solidify in the educational proposals analyzed in the platforms. We are in agreement with Cipollone et al. (2014) in noticing a clear influence of constructivism, not only in Minecraft, but in all the proposals reviewed. Also, there is 
Table 5 Implementation of creative media praxis

\section{Creative media praxis}

MCE The student becomes part of the selected world through an avatar (subjective plane). This is the first key: protagonism in virtual space. The second is creativity. That world can be built, deconstructed and crafted. In Minecraft Education Edition the so-called lessons are those that grant objectives and purposes. Forums and community are highlighted in the platform model. This last one is twofold. On the one hand, teachers around the application. On the other hand, diegetics, by enabling multiplayer connection under the same environment for its members.

NFBE From the NFB Education platform, strategies for narrative empowerment are mainly based on the direct link between the digital proposal and the action within the real educational space. While it is true that there are digital tools that allow action and choice online (it is worth highlighting the edition of chapters and playlists), the real potential for the final target (students) is carried out through direct action proposals set in the study guides and learning packages on a didactic level, Live Webinars as proposals related to intellectual fandom, StopMo as a technological tool to enhance creativity, but especially with media-making workshops.

EAR The audiovisual approach stands as a content enhancing support, and the tools as facilitating elements of traditional teaching practice. In their performance, the materials provided (with the focus on personalization, community, accessibility and usability) and the tools do not imply an impairment of the usual classroom procedures, but do seek to implement the capabilities of the networked digital environment.

SCR In its first pillar, that of creativity, Scratch is founded on the power of an editor that allows a wide range of formats, always starting from "sprites" and "scripts", following programming logic. Beyond the development of the projects themselves; it inserts them into a community that enhances their value. The collaborative creation environment in the community is not an accessory: it is part of the genesis and idiosyncrasy of the platform itself.

7DC Audiovisual literacy and the participation included in its conceptual approach dissociates itself from mediated creation procedures, guiding the knowledge of film and related subjects from the expert public's perspective or academic research, rather than as a shooting team that pursues the making of a film.

proximity with tenets of cognitivism, connectivism and the influence of the maker and DIY movements.

The creative praxis is enhanced by technological tools, in line with the "power up" described by Gee and Hayes (2011). The creation of playlists and mental maps starting with audio-visual materials, the re-invention of projects in the Scratch editor, the construction of the Minecraft Universe indicated by the lessons...There is a great variety of proposals that are intertwined with the Freinetian tenets and his maxim stating "Il faut, à la base, l'activité et l'action" (Freinet, 1952).

Another "Freinetian" characteristic is the positioning of the community as a central element of the education act (Freinet, 1986). It is here where creativity makes complete sense, under an active community, motivated and involved in the projects. In most of the researched cases, the platforms offered a digital community model based on the identity (profiles), projects (creations) and socialization tools (likes, comments, follows, wikis, forums, etc). The paradigmatic example is the one from Scratch, with the connection between ideas, interests and people (Brennan \& Resnick, 2013), and on which diverse studies, such as the one by Sáez-López, Román-González, and undefined Vázquez-Cano (2016) determined "several advantages, such as motivation, fun, commitment, and enthusiasm" in their users.

The community models, except for that of the 7 de Cinema suitcase, come from the digital environment as the central element, and permeate the physical spaces. Proposals such as live webinars or the workshops by NFB Education extend the teaching/training formula beyond the frontiers of the platform. Nevertheless, in most cases, the environments analyzed offer a closed approach; their offer is comprehensive under the umbrella of the plat- 
form, with connectivity to other spheres becoming relegated to the background. The community construction, in this sense, is gestated mainly in the platform's own environment, with scarce options for linking with other external nodes (physical or digital).

Creativity and community do not operate as isolated elements, but are proposed as a pair with a character of evident interdependence and feedback. Creative participation is recognized, makes sense and has a specific value in a community environment. The media practice contributes content, and it is the essential nucleus of the interexchange between the community members, on which motivation and commitment are supported (fandom at a small scale). Also, there is a strong identity component: the user recognizes him or herself, and is presented to the others through their creations, as previously shown Hull and Katz (2006).

\section{CONCLUSIONS}

The platforms analyzed, which, from mediated communication, are being linked to learning, constitute an environment that benefits the development of capacities and abilities under the framework offered by an authentic participative culture (Jenkins et al., 2009; Scolari, 2018).

Along this line, motivation, creative participation, the perspective of entertainment and enjoyment, besides the tools that promote the creative value of narration and the exchanges in a community environment, more directly connect with the new ways of thinking as described by Pérez-Rodríguez and Delgado-Ponce (2012) and the cognitive logic of the digital media presented by Naughton (2010) and Considine et al. (2009).

In the analysis, the treatment of creative actions in an active community environment that is emotionally involved is specifically noteworthy as one of the main backbones of com-educational proposals. This perspective finds similarities with the concept of produsage (Bruns \& Schmidt, 2011) and open participation, heterarchy, palimpsest (reinvention in Scratch, for example) and the community property together with personal rewards, gathered through individualized profiles within an environment. At this point it should be highlighted, however, that most of the platforms analyzed did utilize differentiation ranking according to status (in the case of the teacher in Educ'Arte, 7 de Cinema, NFB Education and Minecraft Education) that imitate the traditional model of the school and offer limitations or privileges according to the role given. Thus, despite observing a greater affinity of the com-educational proposals with the Emirec (Cloutier, 1973) than with that of the Prosumer from Toffler and its most economic perspective Toffler (1980) y su perspectiva más economicista Aparici and García-Marín (2018), the ideal of peer to peer communication and the absence of hierarchy do not solidify.

We are conscious of the need to project these findings towards future research studies for a more specific look at the ways in which this interdependence operates, with the intention of identifying the elements that comprise an active and creative community that is also emotionally involved. More specifically, to delve into the formulas and strategies for driving learning through creation, especially to that related to the generative interaction 
among peers, emotions and the feeling of belonging (Sáez-López et al., 2016) and collaborative exchange, which are activated with the use of these platforms, along with an analysis of the potentialities of the connected digital environments and their new ways of intervention, representation, the new narratives, the organization of knowledge and its communicational flows among nodes.

Com-educational platforms offer, in this sense, a solution to a problem that has been contrasted in formal education; that of the learner's demotivation and school abandonment that the National Institute of Statistics has measured at 18.3\% of the youth aged between 18 and 24 in 2017 (INE, 2019).

\section{ACKNOWLEDGEMENTS}

Funded by: Ministry of Science, Innovation and Universities, Spain.

Funder Identifier: http://dx.doi.org/10.13039/100014440

Award: RTI2018-093303-B-I00

\section{REFERENCES}

Aguaded, I. (2012). Media proficiency, an educational initiative that cannot wait. Comunicar, 39, 7-8. https://doi.org/10.3916/C39-2012-01-01

Aparici, R., \& García-Marín, D. (2018). Prosumers and emirecs: Analysis of two confronted theories. Comunicar, 55, 71-79. https://doi.org/10.3916/C55-2018-07

Aparici, R., \& Silva, M. (2012). Pedagogy of Interactivity. Comunicar, 38, 51-58. https://doi.org/ 10.3916/C38-2012-02-05

Area, M., \& Ribeiro, M. T. (2012). From Solid to Liquid: New Literacies to the Cultural Changes of Web 2.0. Comunicar, 38, 13-20. https://doi.org/10.3916/C38-2012-02-01

Bauman, Z. (1999). Modernidad Líquida. Buenos Aires: FCE.

Bazzul, J. (2012). Neoliberal ideology, global capitalism, and science education: engaging the question of subjectivity. Cultural Studies of Science Education, 7(4), 1001-1020. https://doi.org/ 10.1007/s11422-012-9413-3

Brennan, K., \& Resnick, M. (2013). Stories from the scratch community: Connecting with ideas, interests, and people. SIGCSE 2013 - Proceedings of the 44th ACM Technical Symposium on Computer Science Education (pp. 463-464).

Bruns, A., \& Schmidt, J. H. (2011). Produsage: a closer look at continuing developments. New Review of Hypermedia and Multimedia, 17(1), 3-7. https://doi.org/10.1080/13614568.2011.563626

Buckingham, D. (2007). Media education goes digital: an introduction. Learning, Media and Technology, 32(2), 111-119. https://doi.org/10.1080/17439880701343006

Cipollone, M., Schifter, C. C., \& Moffat, R. A. (2014). Minecraft as a creative tool: A case study. International Journal of Game-Based Learning, 4(2), 1-14. https://doi.org/10.4018/ ijgbl.2014040101

Cloutier, J. (1973). La communication audio-scripto-visuelle à l'heure des self média. Montreal: Les Presses de l'Université de Montreal. https://doi.org/10.3406/colan.1973.4033

Considine, D., Horton, J., \& Morrman, G. (2009). and Reading the Millennial Generation Through Media Literacy. Journal of Adolescent \& Adult Literacy, 52(6), 471-481. https://doi.org/10 .1598/JAAL.52.6.2 
Corbetta, P. (2007). Metodología y técnicas de investigación social. Madrid: McGraw HillInteramericana de España.

Ferrés, J., Aguaded, I., \& García-Matilla, A. (2012). La competencia mediática de la ciudadanía española: dificultades y retos. Revista ICONO14, 10(3), 23-42. https://doi.org/10.7195/ri14 .v10i3.201

Ferrés, J., \& Piscitelli, A. (2012). La competencia mediática: propuesta articulada de dimensiones e indicadores. Comunicar, XIX, 19(38), 75-82. https://doi.org/10.3916/C38-2012-02-08

Franklin, D., Conrad, P., Boe, B., Nilsen, K., Hill, C., Len, M., ... Aldana, G. (2013). Assessment of computer science learning in a scratch-based outreach program. 44th SIGCSE Technical Symposium on Computer Science Education. New York: ACM.

Freinet, C. (1952). Le cinéma au service de l'école moderne et de la vie. Enfance, $2(171-176)$. https://doi.org/10.3406/enfan.1952.1241

Freinet, C. (1986). Por una escuela del pueblo. Barcelona: Laia.

García, J. D., Rigo, E., \& Jiménez, E. (2017). Multimedia and Textual Reading Comprehension: Multimedia as Personal Learning Environment's Enriching Format. Journal of New Approaches in Educational Research, 6(1), 3-10. https://doi.org/10.7821/naer.2017.1.180

Gee, J., \& Hayes, E. (2011). Language and learning in the digital age (and others, Ed.). New York: Routledge. https://doi.org/10.4324/9780203830918

Gutiérrez, A., \& Tyner, K. (2012). Media Education, Media Literacy and Digital Competence. Comunicar, 19(38), 31-39. https://doi.org/10.3916/C38-2012-02-03

Hull, G., \& Katz, M. L. (2006). Crafting an Agentive Self: Case Studies on Digital Storytelling. Research in the Teaching of English, 41(1), 43-81.

INE. (2019). Abandono educativo temprano de la población de 18 a 24 años por CCAA y periodo. [Blog post]. Retrieved from http://www.ine.es/jaxi/Datos.htm

Jenkins, H. (2008). Convergence culture. New York: New York: University Press.

Jenkins, H., Purushotma, R., Weigel, M., Clinton, K., \& Robison, A. (2009). Confronting the Challenges of Participatory Culture Media Education for the 21st Century. Cambridge: The MIT Press. Retrieved from https://mitpress.mit.edu/sites/default/files/titles/free_download/ 9780262513623_Confronting_the_Challenges.pdf https://doi.org/10.7551/mitpress/8435 .001 .0001

Livingstone, S. (2012). Critical reflections on the benefits of ICT in education. Oxford Review of Education, 38(1), 9-24. https://doi.org/10.1080/03054985.2011.577938

Manovich, L. (2005). El lenguaje de los nuevos medios de comunicación: La imagen en la era digital. Barcelona: Paidos Ibérica.

Martín, J. (2008). The explosion of narratives and the multiplication of readings. Comunicar, 30, 15-20. https://doi.org/10.3916/c30-2008-01-002

Naughton, J. (2010, june 20). Everything you ever needed to know about the Internet. Retrieved from www.guardian.co.uk/technology/2010/jun/20/internet-everything-need-to-know

Pauwels, L. (2012). A multimodal framework for analyzing Websites as cultural expressions. Journal of computer-mediated, 17(3), 247-265. https://doi.org/10.1111/j.1083-6101.2012.01572.x

Pereira, S., Fillol, J., \& Moura, P. (2019). Young people learning from digital media outside of school: The informal meets the formal. [El aprendizaje de los jóvenes con medios digitales fuera de la escuela: De lo informal a lo formal]. Comunicar, 58, 41-50. https://doi.org/ 10.3916/C58-2019-04

Pérez-Rodríguez, M. A., Contreras-Pulido, P., \& Delgado-Ponce, A. (2018). La competencia mediática en el escenario de la convergencia digital. In I. Aguaded, L. M. Romero-Rodríguez, et al. (Eds.), Competencias mediáticas en medios digitales emergentes (pp. 29-49). Salamanca: Comunicación Social. 
Pérez-Rodríguez, M. A., \& Delgado-Ponce, A. (2012). De la competencia digital y audiovisual a la competencia mediática: dimensiones e indicadores. Revista Comunicar, 39, 25-34. https:// doi.org/10.3916/C39-2012-02-02

Pérez-Rodríguez, M. A., Delgado-Ponce, A., García-Ruiz, R., \& Caldeiro, M. C. (2015). Niños y jóvenes ante las redes y las pantallas. Barcelona: Gedisa.

Pérez-Rodríguez, M. A., Pérez-Escoda, A., \& Sánchez-López, I. (2019). De lo audiovisual a lo transmedia. Competencias para las nuevas narrativas de los prosumidores en el ecosistema digital. In L. M. Romero-Rodríguez \& D. Rivera-Rogel (Eds.), La comunicación en el escenario digital. Actualidad, retos y prospectivas (pp. 119-149). México: Pearson Educación.

Pérez-Tornero, J. M. (2013). Midiendo la Alfabetización Mediática en Europa 2005-2010. Barcelona: Universitat Autònoma de Barcelona.

Pérez-Tornero, J. M., \& Martínez-Cerdá, J. F. (2011). Hacia un sistema supranacional de indicadores mediáticos. Infoamérica, 5, 39-57.

Piaget, J. (2007). La representación del mundo en el niño. Madrid: Morata.

Sáez-López, J. M., Román-González, M., \& undefined Vázquez-Cano. (2016). Visual programming languages integrated across the curriculum in elementary school. Computers \& Education, 97, 129-141. https://doi.org/10.1016/j.compedu.2016.03.003

Santander, P. (2011). Por qué y cómo hacer análisis de discurso. Cinta Moebio, 41, 207-224. https:// doi.org/10.4067/S0717-554X2011000200006

Scolari, C. (2018). Adolescentes, medios de comunicación y culturas colaborativas. Aprovechando las competencias transmedia de los jóvenes en el aula. Barcelona: Universitat Pompeu Fabra.

Toffler, A. (1980). The third wave. New York: Bantam Books.

Tondeur, J., Braak, J. V., Sang, J., Voogt, J., Fisser, P., \& Ottenbreit-Leftwich, A. (2012). Preparing pre service teachers to integrate technology in education: a synthesis of qualitative evidence. Computers Education, 59(1), 134-144. https://doi.org/10.1016/j.compedu.2011.10.009

Vygotsky, L. S. (2004). Imagination and creativity in childhood. Journal of Russian and East European Psychology, 42(1), 7-97. https://doi.org/10.1080/10610405.2004.11059210 